\title{
EKSPRESI CINTA PADA NOVEL “BIDADARI BIDADARI SURGA” KARYA TERE-LIYE
}

\author{
Theresia Sri Susetianingsih \\ SMA Negeri Sragen \\ theresia.sri@gmail.com
}

\begin{abstract}
Abstrak
Penelitian ini bertujuan untuk menggambarkan dan menjelaskan karakter ekspresi cinta dalam novel "Bidadari Bidadari Surga". Berdasarkan hasil analisis dapat disimpulkan bahwa karakter cinta ekspresi dalam novel sebagai modal yang potensial dalam keluarga mereka, ekspresi karakter cinta adalah (a) memberikan cinta dan perasaan aman, (b) memberikan perhatian kepada anggota keluarga, (c) membangun perilaku sifat anggota keluarga, dan (d) memberikan identitas keluarga.

The arms of the research are to describe and explain the characters love expressions in her novel "Bidadari Bidadari Surga". The characters love expressions in the novel as an intense modal todevelop the potensial in theirs family, the characters love expressions are as follows (a) giving love and secure feelings, (b) giving attentions to the family members, (c) building the nature behavior of the family members, and (d) giving the family identities.
\end{abstract}

Key words: Novel, Authors, An Educational Value and Literrary Sociology

\section{A. Pendahuluan}

Karya sastra adalah bentuk kreativitas dalam bahasa yang indah berisi sederetan pengalaman batin dan imajinasi yang berasal dari penghayatan realitas sosial pengarang. Karena karya sastra adalah suatu bentuk dan hasil pekerjaan seni yang objeknya adalah manusia dan kehidupannya dengan menggunakan bahasa sebagai media. Karya sastra merupakan ungkapan batin seseorang melalui bahasa dengan cara penggambaran. Penggambaran atau imajinasi ini dapat merupakan titian terhadap kenyataan hidup, wawasan pengarang terhadap kenyataan kehidupan, dapat pula imajinasi murni pengarang yang tidak berkaitan dengan kenyataan hidup (rekam), atau dambaan intuisi pengarang, dan dapat pula sebagai gabungan keduanya.

Karya sastra yang ditulis merupakan ungkapan masalah-masalah manusia dan kemanusiaan, tentang makna hidup dan kehidupan. Ia melukiskan penderitaanpenderitaan manusia, perjuangannya, kasih sayang dan kebencian, nafsu, dan segala yang dialami manusia (Esten, 1990:8). Bentuk pengungkapan inilah yang 
merupakan hasil kepiawaian pengarang dalam menggambarkan segala aspek kehidupan manusia lewat ekspresi pengarang. Dengan demikian, karya sastra diciptakan pengarang untuk dinikmati, dihayati, dan dimanfaatkan bagi khalayak (pembaca).

Karya sastra lahir karena adanya sesuatu yang menjadikan jiwa seorang pengarang atau pencipta mempunyai rasa tertentu pada suatu persoalan atau peristiwa di dunia ini, baik yang langsung dialaminya maupun dari kenyataan hidup sehari-hari yang ada di masyarakat. Persoalan atau peristiwa itu sangat memperngaruhi bentuk kejiwaan seorang pencipta karya sastra, sehingga memungkinkan munculnya konflik atau ketegangan batin yang mendoraong pencipta untuk mewujudkan konflik atau ketegangan batin tersebut dalam bentuk karya sastra.

Karya sastra yang ditulis merupakan ungkapan masalah-masalah manusia dan kemanusiaan, tentang makna hidup dan kehidupan. Ia melukiskan penderitaanpenderitaan manusia, perjuangannya, kasih sayang dan kebencian, nafsu, dan segala yang dialami manusia (Mursal Esten, 1990:8). Bentuk pengungkapan inilah yang merupakan hasil kepiawaian pengarang dalam menggambarkan segala aspek kehidupan manusia lewat ekspresi pengarang. Dengan demikian, karya sastra diciptakan pengarang untuk dinikmati, dihayati, dan dimanfaatkan bagi khalayak (pembaca).

Karya sastra diciptakan pengarang tentu mempunyai maksud-maksud tertentu. Karya sastra tidak hanya untuk menghibur, tetapi merupakan alat menyampaikan wejangan-wejangan atau nasihat, pendidikan dan sebagainya. Dengan karyanya seorang pengarang bermaksud menyampaikan gagasan-gagasannya, pandangan hidup atas kehidupan sekitar dengan cara menarik dan menyenangkan pembaca untuk berbuat baik. Pesan ini dinamakan "moral" yang biasa disebut amanat (Panuti Sudjiman, 1998: 57).

Novel Bidadari-Bidadari Surga berkategori novel yang mengungkapkan kehidupan sarat makna kerja keras, perjuangan, cinta keluarga, pengorbanan, dan penghormatan yang begitu nyata dalam kehidupan. Oleh karena itu novel BidadariBidadari Surga dapat dianalisis berdasarkan pendekatan sosiologi sastra. Dengan pendekatan sosiologi sastra akan mampu mengungkapkan keberadaan manusia dalam menghadapi masalah-masalah yang timbul dalam kehidupan yang melingkupinya. Permasalahan yang diangkat dalam novel BBS merupakan refleksi 
dari kenyataan yang ada dalam kehidupan sosial ekonomi sederhana yang terbatas di perkampungan Lembah Lahambay yang merupakan tempat yang sebagian besar melatari cerita.

Bardasarkan latar belakang masalah yang telah diuraikan di atas, maka rumusan masalah dalam penelitian ini adalah sebagai berikut, (1) bagaimanakah pandangan dunia pengarang dalam novel $B B S$; (2) bagaimanakah tokoh mengekspresikan cinta dalam novel $B B S$; (3) bagaimanakah tokoh membangun ekonomi keluarga dlm novel $B B S$; dan (3) nilai- nilai pendidikan apa yg terungkap dlm novel $B B S$.

\section{Novel Sebagai Sebuah Karya Sastra}

Sumardjo (1992: 3) memberikan batasan tentang sastra adalah ungkapan pribadi manusia yang berupa pengalaman, pemikiran, perasaan, ide, semangat, keyakinan dalam suatu bentuk gambaran kongkret yang membangkitkan pesona dengan alat bahasa. Dalam kaitan ini terlihat bahwa peran perasaan cukup besar dalam proses pengkajian atau penulisan karya sastra.

Sementara itu, dapat dikemukakan bahwa definnisi sastra adalah ciptaan manusia dalam bentuk bahasa lisan ataupun tulis yang dapat menimbulkan rasa bagus. Keindanan merupakan objek yang secara langsung dan hanya dapat ditangkap oleh indera manusia, terutama yang berkaitan dengan aspek kejiwaan afektif yang dikenal dalam proses pembelajaran selama ini (Badudu, 1984: 5).

Jan Van Luxemburg yang (1984: 4-5) menyebutkan ciri sastra yaitu: (1) Sastra merupakan sebuah ciptaan, sebuah kreasi bukan pertama-tama sebuah imitasi. Sasatrawan menciptakan sebuah dunia baru, meneruskan proses penciptaan di dalam semestan alam, bahkan menyempurnakannya. Sastra terutama merupakan suatu luapan emosi yang spontan. (2) Sastra bersifat otonom, tidak mengacu pada sesuatu yang lain; sastra tidak bersifat komunikatif. (3) Karya sastra yang otonom itu mempunyai koherensi antara bentuk dan isi, saling berhubungan antara bagian dengan keseluruhan secara erat sehingga saling menerangkan. (4) Sastra menghidangkan sebuah sintesa antara hal-hal yang saling bertentangan. (5) Sastra mengungkapkan hal-hal yang tak terungkapkan. Dalam sastra dijumpai sederetan arti yang dalam bahasa sehari-hari tak terungkapkan. 
Sampai pada kesimpulan tentang sastra, Teeuw (1984: 41) mengatakan bahwa tidak ada kriteria yang jelas yang dapat diambil dari perbedaan pemakaian bahasa lisan dan bahasa tulis untuk membatasi sastra sebagai gejala khas. Ada pemakaian bahasa lisan dan tulis yang sastra; dan sebaliknya ada sastra tulis dan ada sastra lisan.

Berangkat dari pengertian sastra yang bermacam-macam di atas, penulis ingin mendefinisikan sastra berdasarkan pendekatan sastra yang dikemukakan oleh M.H. Abrams, dengan pendekatan objektif, pendekatan ekspresif, pendekatan mimetik, dan pendekatan pragmatik (Teeuw, 1984: 50).

Berdasarkan pendekatan objektif, sastra dapat didefinisikan sebagai karya seni yang otonom, berdiri sendiri, bebas dari pengarang, realitas, maupun pembaca. Berdasarkan pendekatan ekspesif, karya sastra dipandang sebagai ekspresi sastrawan, atau sebagai produk imajinasi sastrawan. Berdasarkan pendekatan mimetik, karya sastra dianggap sebagai tiruan alam, tiruan kehidupan, tiruan kenyataan. Berdasarkan pendekatan pragmatik, karya sastra dipandang sebagai sarana untuk menyampaikan tujuan tertentu, seperti nilai atau ajaran kepada pembaca.

Kajian sastra pada dasarnya akan memberikan interpretasi dan penilaian terhadap suatu fenomena sastra, dan hakikatnya yang tersembunyi di dalam sistem tanda yang berupa karya sastra. Pada dasarnya penilaian karya sastra ada tiga paham penilaian yang penting yaitu:relativisme, absolutisme, dan perspektivisme (Rachmat Djoko Pradopo, 2003: 49).

Goldmann ( dalam Wardani, 2009: 15) menyatakan novel sebagai cerita tentang suatu pencarian yang berdegredasi akan nilai-nilai otentik yang dilakukan oleh hero yang problematik dalam sebuah dunia yang juga berdegredasi. Yang dimaksud dengan nilai-nilai yang otentik menurut Goldmann tersebut adalah nilainilai yang mengorganisasikan dunia-dunia novel secara keseluruhan meskipun hanya secara implisit, nilai-nilai itu hanya ada dalam kesadaran si novelis, tidak dalam karakter-karakter sadar atau realitas konkrit, singkatnya nilai-nilai otentik itu adalah totalitas kehidupan.

Novel merupakan bagian dari genre prosa fiksi. Berkaitan dengan pengertian novel sebagai karya sastra berbentuk prosa fiksi, perlu pula dipahami 
terlebih dahulu pengertian tentang fiksi. Abrams (1971: 59) menjelaskan bahwa yang dimaksud dengan fiksi adalah:

Fiction in the inclusive sense, is any narrative which is feigned or invented rather than historically or factually true. In most present day discussion, however, the term fiction is applied primarily to prose narratives (the novel and the story), and is sometimes used simply as synonym for novel.

Berdasarkan pendapat Abrams dapat dijelaskan bahwa fiksi adalah cerita rekaan atau dibuat- buat, sedangkan yang termasuk fiksi adalah novel dan cerpen.Namun kadangkala fiksi juga sering digunakan sebagai sinonim dari novel. Herman J. Waluyo sependapat dengan Abrams, bahwa yang dimasud karya fiksi adalah:

Fiksi dari kata fiction yang artinya hasil khayalan atau sesuatu yang sebenarnya tidak ada. Cerita- cerita sastra, seperti roman, novel, dan cerita pendek diklasifikasikan sebagai prosa fiksi, sedangkan prosa yang bukan karya sastra yang merupakan deskripsi dari kenyataan dinyatakan sebagai prosa non fiksi, misalnya:biografi, catatan harian, laporan kegiatan, dan sebagainya yang merupakan karya yang bukan hasil imajinasi, (2009: 1).

Dari uraian sejumlah ahli, dapat disimpulkan bahwa novel adalah sebuah karya prosa fiksi yang tertulis dan naratif, biasanya dalam bentuk cerita. Penulis novel disebut novelis. Kata novel berasal dari bahasa Italia novella yang berarti "sebuah barang baru". Novel lebih panjang (setidaknya 40.000 kata) dan lebih kompleks dari cerpen. Panjangnya novel karena karakter tokohnya

\section{Kajian Sosiologi Sastra}

Sosiologi adalah pengetahuan atau ilmu tentang sifat, perilaku, dan perkembangan masyarakat; sedangkan sosiologi sastra berarti sastra karya para kritikus dan sejarawan yang terutama mengungkapkan pengarang yang dipengaruhi oleh status lapisan masyarakat tempat ia berasal, ideologi politik dan sosialnya, kondisi ekonomi serta khalayak yang ditujunya (KBBI, 1994: 958). Leo Lowental $(2010 ; 1)$ :

"Science of society, social institutions, and social relationships, and specifically the systematic study of the development, structure, interaction, and collective. Behaviour of organized human groups. It emerged at the end of the $19^{\text {th }}$ century through the work of Emile 
Journal Indonesian Language Education and Literature Vol.1, No. 2, 2016

http://www.syekhnurjati.ac.id/jurnal/index.php/jeill/

Durkheim un france, Max Weber and George Simmel in Germany, and Robert E. Park and Albion Small in the USA. Sociologist use observational techniques, surveys and interviews, statical analysis, controlled experiments, and other methods to study subjects such as the family, Ethnic relations, schooling, social status and class, bureaucracy, religious movements, deviance, the elderly, and social."

Sosiologi adalah ilmu pengetahuan yang objek studinya berupa aktivitas sosial manusia. Sastra adalah karya seni yang merupakan ekspresi kehidupan manusia. Dengan demikian, antara karya sastra dan sosiologi sebenarnya merupakan dua bidang berbeda, tetapi keduanya saling melengkapi. Sosiologi tidak hanya menghubungkan manusia dengan lingkungan sosial budaya, tetapi juga dengan alam. Kajian sosiologi sastra yang menonjol adalah yang dilakukan kaum Marxisme yang mengemukakan bahwa sastra adalah refleksi masyarakat yang dipengaruhi oleh kondisi sejarah, Egleton (dalam Zainudin Fananie, 2000: 132) Sastra karenanya, merupakan suatu refleksi lingkungan budaya dan merupakan satu tes dielektika antara pengarang dengan situasi sosial membentuknya atau merupakan penjelasan suatu sejarah dialektik yang dikembangkan dalam karya sastra, Langland (dalam Zainudin Fananie, 2000: 132).

Menurut Laurenson (1972) terdapat tiga perspektif berkaitan dengan sosiologi sastra :

a. Perspektif yang memandang sastra sebagai dokumen sosial yang didalamnya merupakan refleksi situasi pada masa sastra tersebut diciptakan,

b. Perspektif yang mencerminkan situasi sosial penulisnya,

c. Model yang dipakai karya tersebut sebagai manifestasi dari kondisi sosial budaya atau peristiwa sejarah. (dalam Zainudin Fananie, $2000: 133)$

Karya sastra merupakan dunia kemungkinan, artinya ketika pembaca berhadapan dengan karya sastra, maka ia berhadapan dengan kemungkinan penafsiran. Sosiologi sastra sebagai landasan teori dalam menganalisis novel. Menurut pandangan teori ini, karya sastra dilihat hubungannya dengan kenyataan, sejauh mana karya sastra itu mencerminkan kenyataan. Kenyataan di sini mengandung arti cukup luas, yakni segala sesuatu berada di luar karya sastra yang diacu oleh karya sastra. 


\section{Hakikat Cinta dalam Keluarga}

Setiap orang memiliki pengertian yang tidak sama tentang cinta. Seorang ibu mengartikan perasaannya terhadap anaknya adalah cinta, seorang kakak mengartikan perasaanya pada adiknya adalah cinta, seorang sahabat mengartikan perasaanya terhadap sahabat adalah cinta, serta perasaan kepada lawan jenis juga disebut cinta. Tidak ada pengertian yang salah. Semua tergantung siapa yang mengalami cinta serta kepada siapa perasaan itu ditujukan, seperti yang dijelaskan Firman Allah yaitu:

"Dijadikan indah pada (pandangan) manusia kecintaan pada apa- apa Yang dingini yaitu: wanita- wanita, anak- anak, harta banyak dari emas perak, kuda pilihan, binatang- binatang ternak dan sawah lading. Itulah kesenangan hidup di dunia; dan di sisi Allah-lah tempat kembali yang baik (surga)." (Q.S Al-Imron): 14)

Cinta adalah sebuah perasaan yang ingin membagi bersama atau sebuah perasaan afeksi terhadap seseorang. Pendapat lainnya, cinta adalah sebuah aksi/kegiatan aktif yang dilakukan manusia terhadap objek lain, berupa pengorbanan diri, empati, perhatian, memberikan kasih sayang, membantu, menuruti perkataan, mengikuti, patuh, dan mau melakukan apapun yang diinginkan objek tersebut.(Irawati Istadi,2006:12)

Cinta merupakan perasaan bahagia ketika dekat dengan seseorang yang dicintai. Perasaan ini dapat membuat orang yang mengalaminya lebih bersemangat, segar, optimis, serta lebih tegar. Orang yang mengalami cinta bias mengalami cinta bias melakukan sesuatu yang lebih baik dari biasanya seolah mendapat kekuatan baru atau energinya menjadi berlipat ganda. Banyak orang yang mendapatkan prestasi gemilang karena cinta.

Keluarga adalah sebuah tatanan fitrah yang Allah tetapkan bagi jenis manusia, seperti termaktub pada Q.S. Al-A`raf $\{7\}: 189$. Bahkan para rasul dan nabi Allah pun juga menjalani hidup berkeluarga. Hal itu membuktikan bahwa keluarga adalah sebuah institusi suci, mengandung hikmah dan memiliki misi Illahiah secara abadi.

Keluarga adalah sebuah institusi yang keberadaannya lahir bersama penciptaan manusia pertama. Keluarga merupakan sumber terbentuknya suku, bangsa, dan kelompok- kelompok manusia. Pendapat Anthoniy Giddens dalam Saptono (2007:58) "Keluarga adalah institusi dasar masyarakat madani. Kebijakan 
keluarga adalah batu ujian penting bagi politik baru." Sebuah keluarga harus mempunyai strategi politis efektif, yang dapat mempengaruhi dan memperbaiki kondisi keluarga yang ideal. Yang paling fundamental dalam membentuk keluarga yang ideal adalah adanya prinsip kesamaan derajad antarjenis kelamin,dan tidak ada lagi cara untuk mundur dari pinsip ini. Hanya ada satu kisah tentang keluarga yang demokratis.

\section{B. Metode Penelitian}

Penelitian ini merupakan penelitian kualitatif, dengan menggunakan metode kualitatif deskriptif. Data penelitian berupa berwujud kata, frase, kalimat dalam novel BBS, sumber data dokumen novel Bidadari Bidadari Surga, Narasumber: pengarang novel BBS. Teknik cuplikan yang digunakan adalah purposive sampling, bahwa sampel mewakili informasinya. Teknik pengumpulan data melakukan wawancara mendalam (in-depth interviewing), mengkaji dokumen dan arsip (content analysis), dan kuesioner

Uji validasi data melalui triangulasi sumber dari buku ilmiah, jurnal ilmiah, artikel dan narasumber; trianggulasai teori: teori sastra, teori sosiologi, teori sosiologi sastra, teori cinta, teori fungsi keluarga, teori ekonomi; dan trianggulasi metode: teknik pustaka, simak dan catat; serta wawancara. Teknik analisis data yang digunakan adalah analisis interaktif yang meliput tiga komponen yaitu reduksi data, penyajian data, dan simpulan. Reduksi data selalu dilakukan, bila simpulan dirasa kurang, maka data kembali dikumpulkan untuk mencari pendukung simpulan yang telah dikembangkan dan juga sebagai usaha pendalaman data.

\section{Hasil Penelitian dan Pembahasan}

\section{Ekspresi Cinta Tokoh dalam Novel BBS}

Tokoh dalam novel BBS : Kakak Laisa, Dalimunte, Wibisana ,Ikanuri, Yashinta: (1) memberikan kasih sayang dan rasa aman; (2) memberikan perhatian diantara anggota keluarga; (3) membina pendewasaan kepribadian anggota keluarga; (4) memberikan identitas keluarga; dan (4) memberikan kasih sayang dan rasa aman. 


\section{a. Ekspresi Cinta Laisa}

Rasa kasih sayang yang terjadi dalam novel Bidadari Bidadari Surga rasa kasih sayang dalam keluarga, antara kakak dan adiknya.Seorang kakak yang sangat berani mengahadapi bahaya dari terkaman harimau karena rasa kasih sayang dan ingin memberikan rasa aman kepada adik- adiknya. Saat Iknuri dan Wibisana hampir jatuh pingsan, ketakutan. Saat harimau terbesar yang berada paling dekat bersiap meloncat. Saat itulah Kak Laisa menunaikan janjinya.

\footnotetext{
',TIDAK! TIDAK BOLEH!"

Terhenti. Gerakan tubuh harimau terbesar itu terhenti.

"TIDAK! PUYANG TIDAK BOLEH MEMAKAN MEREKA!" Kak Laisa, entah apa yang ada di kepalanya, yang sedetik baru tiba di sana, sedetik terpana menyaksikan pemandangan di depannya, tanpa berpikir panjang, seperseriby detik langsung loncat dari balik semak, menerobos ke tengah kerumunan. Mukanya terlihat begitu tegang. Ia sungguh gentar. Ia sungguh ketakutan. Siapa pula yang tidak akan jerih melihat tiga ekor harimau dari jarak dua meter tanpa penghalang? Tapi perasaan itu, perasaan melindungi adik-adiknya membuat Laisa menyeruak, nekad masuk ke arena kematian, (Tere Liye, 2008: 130).
}

Kutipan di atas menjelaskan bahwa perasaan kasih sayang yang tulus ikhlas dan tegas yang tidak perlu berlama- lama menunggu, dengan cara yang cepat untuk menghadapi resiko yang besar yaitu mati diterkam harimau yang lapar. Hal tersebut dilakukan karena untuk melindungi adik- adiknya.Sebuah pengorbanan yang mahabesar dalam cinta dan kasih sayang yang sepenuh hati dari seorang kakak kepada adik-adiknya. Kakak memberikan goresan catatan yang bermakna pengorbanan, perjuangan dan cinta.

\section{b. Ekspresi Cinta Mamak}

Ekspresi atau perwujudan cinta seorang ibu yang selalu memberikan kasih sayang dan rasa aman. Kemauan, tekad, usaha, dan kerja keras orang tua untuk anaknya. Siapapun pasti memiliki keluarga bahagia. Lantas bagaiman caranya membuat kehidupan dalam keluarga berjalan seimbang? Bagaiman menumbuhkan benih- benih cinta dan kasih sayang di dalam hati setiap anggota keluarga? Kuncinya adalah dari kesadaran diri kita sendiri sebagai anggota keluarga. Cara kita menjalani kehidupan inilah yang akan menentukan berhasil tidaknya kita membina sebuah keluarga yang harmonis, antara orang tua, anak, kakak- adik, keluarga, kerabat,bahkan keluarga sesamanya. 
Lepas maghrib, saat orang-orang pulang dari surau, deting kecemasan itu mulai tumbuh. Mamak Linuri menatap cemas dari bingkai jendela depan yang masih terbuka. Kemana pula dua anak nakalnya pergi?

Adzan isya. Lepas shalat isya. Lembah sempurna gelap. Dan sedikit pun tidak kelihatan tanda-tanda batang-hidung Ikanuri dan Wibisana. Mamak semakin cemas. Menatap siluet hutan rimba dengan nafas bergetar.

Pukul 19.30. tegang sekali

Pukul 20.00, mamal Linuri akhirnya menyerah.

Sejengkel apapun ia dengan Ikanuri dan Wibisana, dawai kecemasannya sudah berdeting terlalu tinggi. Ia menyambar obor di depan pintu. Melangkah cepat ke rumah Wak Burhan. Kak Laisa, yang meski hatinya masih bagai buah terdayat-dayat sejak kejadian tadi sore ikut ke rumah Wak Burhan. Mamak hendak melapor. Dua anaknya belum pulang. (Tere Liye, 2008:114)

Dari kutipan di atas menggambarkan kecemasan hati seorang ibu yang dilanda kegelisahan. Ketika hari sudah malam dua anaknya laki- laki belum pulang ke rumah. Kedua anak laki-laki ini memang agak berbeda suka berpatualang. Akan tetapi hari itu sampai malam belum pulang ada kecemasan dari keluarga di Lembah bahwa perkampungan mereka yang dekat dengan hutan, apalagi bayangan masa lalu kisah suami atau bapaknya muncul yaitu meninggalnya karena diterkam harimau. Hal tersebut membuat suasana semakin menegangkan.

"Kau harus ke dokter, Lais ....Lihatlah darah ini ...." Mamak menelan ludah, menaatap getir bercak darah di baju Laisa.(Tere Liye, 2008:287)

\section{c. Ekspresi Cinta Dalimunte}

Keluarga secara harafiah terdiri dari orang tua dengan anak-anaknya, atau kerabat. Namun, keluarga secara naluri adalah orang-orang terdekat yang sagat mempengaruhi hidup kita, yang melakukan segala sesuatu dengan tulus ikhlas demi kebahagiaan dan kebaikan kita. Siapakah pendekar dalam hidup kita? Apakah ada pendekar dalam hidup kita yang dipandang sebelah mata oleh orang lain, tetapi justru berarti besar dalam hidup kita?

"Aku ikut!" Dalimunte menjawab tegas. Cepat berlari ke dalam rumah. Suara kakinya membuat lantai rumah panggung mereka berderak. Sejurus, Dia sudah keluar lagi, membawa tombak panjang peninggalan Babak.

"Aku ikut kemana pun Kak Laisa pergi malam ini" Tegas sekali Dalimunte berkata. Wajahnya dipenuhi ekspresi penghargaan. Keberanian? Tentu saja Dia takut, dia tahu Kakaknya akan pergi ke Gunung Kendeng. Tapi sumpah, Dali tidak takut mesti harus memasuki daerah terlarang itu. Lihatlah wajah Kak Lais, wajah yang selalu berani dalam hidupnya, demi adik- adik mereka. Wajah yang selalu melindungi. Melihat wajah itu, Dali tidak akan pernah takut lagi.(Tere LIye, 2008:122) 
Dari kutipan di tas dapat diketahui karena rasa kasih sayang seorang kakak yang besar, maka akan selalu memberikan perlindungan. Antara Kakak Laisa dengan adik- adiknya, dan Dalimunte yang ingin melindungi kakaknya dalam perjalanan menelusuri hutan mencari adiknya yang mungkin tersesat di hutan.

\section{d. Ekspresi Cinta Ikanuri dan Wibisana}

Memberikan kasih sayang antara anggota keluarga merupakan perwujudan pemahaman arti kehidupan yang dalam. Hidup adalah anugerah dan kebahagiaan, dan cinta dalam kasih yang tulus adalah kesempurnaan hidup. Cinta merupakan rahasia kemanusiaan yang di dalamnya terkandung hasrat ingin memberi dan melindungi.

Kereta ekspress eurostar itu melesat membelah indahnya kota Paris. Semburat muncul di angkasa. Pagi dating menjelang. Membuat gemerlaplampu kota yang belum dimatikan telihat begitu menawan. Kabut pagi menambahnya syahdu.

"Sudahlah Ikanuri..." Wibisana mendekap bahu adiknya

"Kau tahu.... Kau tahu, waktu itu aku mengatakan Kak Laisa bukan Kakak kita. Kau tahu itu !'’kanuri tersedak. Mendekap wajahnya. Dia tidak bisa lagi menahan persaan itu. Dan melihatnya tertunduk menangis sungguh menyedihkan. Wahai, kalian akan lebih terharu saat melihat seseorang yang selama ini dikenal nakal, tukang jahil, bebal, atau apalah tiba- tiba menangis. Sungguh.

"Kak Laisa tidak pernah marah dengan itu, Ikanuri." Wibisana mengusap bahu adiknya.

Ikanuri justru terdsedan lebih kera. Itu benar sekali.Kak Laisa tidak pernah marah soal itu seikitpun. Tidak pernah. Bahkan Kak Laisa tidak pernah mngungkit-ungkitnya lagi. Ya Allah, karena itulah dia merasa bersalah sekali. Menyesalinya sepanjang hidup. Duapuluh lima tahun berlalu, Ketika takdir kehidupan yang lebih baik menjemput keluarga sederhana mereka di Lembah Lahambay, bahkan ia tidak pernah meminta maaf untuk soal itu. Meski Kak Laisa sebenarnya sudah memaafkan detik itu juga di bawah pohon mangga tersebut. Tapi dia selama ini tidak penah merasa harus meminta maaf. Bagaimana jika mereka terlambat dan tidak ada waktu lagi?

"Tolong.... Tolong sambungkan lagi ke Mamak ..."

"Semoga kita tidak datang terlambat." Ikanuri mengeluh sekali lagi.Itu benar- benar keluhan tertahan. Wibisana menepuk-nepuk bahu Ikanuri. Tersenyum. Berbisik, "Tidak akan terjadi apa-apa, Ikanuri. Kita akan tiba tepat waktu.

Berdoalah, Kak Laisa akan baik-baik saja...."

Hujan turun semakin deras. Badai semakin kencang, (Tere Liye, 2008: 95), 
Journal Indonesian Language Education and Literature Vol.1, No. 2, 2016

http://www.syekhnurjati.ac.id/jurnal/index.php/jeill/

\section{e. Ekspresi Cinta Yashinta}

Keluarga secara harafiah terdiri dari orang tua dengan anak-anaknya, atau kerabat. Namun, keluarga secara naluriah adalah orang-orang terdekat yang sagat mempengaruhi hidup kita, yang melakukan segala sesuatu dengan tulus ikhlas demi kebahagiaan dan kebaikan kita. Siapakah pendekar dalam hidup kita? Apakah ada pendekar dalam hidup kita yang dipandang sebelah mata oleh orang lain, tetapi justru justru berarti besar dalam hidup kita?

\section{Simpulan}

Pandangan Dunia Pengarang dalam Novel BBS adalah keluarga petani sarat dengan kerja keras dan selalu siap menghadapi berbagai perubahan. Tere Liye mengangkat cerita kehidupan yang sederhana dari keluarga petani yang bekerja keras untuk mencukupi kebutuhannya, disertai pengorban dan keikhlasan unuk mencapai kesuksesan yang semuanya diceritakan sangat.

Cara mengungkapkan cinta para tokoh terhadap keluarga. Karen Cinta sebagai modal utama yang sangat berharga untuk mengembangkan potensi yang ada pada keluarga. Dalam mengembangkan potensi yang ada pada keluarga ada beberap unsur dasar yang perlu dipertimbangkan dalam mengekspresikan cinta sesuai fungsi keluarga untuk aspek fungsi psikologis adalah: (1) memberikan kasih sayang dan rasa aman; (2) memberikan perhatian diantara anggota keluarga; (3) membina pendewasaan kepribadian anggota keluarga; dan (4) memberikan identitas keluarga.

\section{Daftar Pustaka}

Abrams, M.H. 1981. The Mirror And The Latril: Romantic Theory And The Critical Tradition. New York: Oxford University Press.

J.S Badudu. 1984. Sari Kesusasteruan Indonesia. Bandung: Pustaka Prima.

Herman J. Waluyo.1992.Pengajaran Sastra yang Berpusat pada Sastra: Seminar Sehari Dalam Rangka Memperingati Hari Sumpah Pemuda Ke-64 Dan Penyelenggaraan Bulan Bahasa Th 1992 Guru. SLTP/ SLTA Se-Kabupaten Sragen. . 2009. Pengkajian Prosa Fiksi. Surakarta: Universitas Sebelas Maret.

Irawati Istadi.2006. Mendidik dengan Cinta. Bekasi: Pustaka Inti Ismawanto. 2007. Ekonomi untuk SMA dan MA Kelas X. Sukoharjo: Gema Ilmu. Jakob, Sumarjo. 1984. Novel Indonesia Mutakhir: Sebuah Kritik. Yogyakarta: C.V. Nur Cahaya. 1999. Pendidikan, Nilai dan Sastra. Jakarta: Grasindo. 
Kaswardi E. M. K. 2000. Pendidikan Nilai Memasuki Th. 2000. Jakarta: Gramedia Widiasarana.

Lexy J. Moleong. 1998. Metodologi Penelitian Kualitatif. Bandung Remaja Rosdakarya.

Liye, Tere. 2008. Bidadari-Bidadari Surga. Jakarta: Republika.

Lowental, Leo.2000. Sociology .Journal of Literature Vol 5. No 2. pp.206-210.

(KBBI, 1994: 958). http://www.answers.com/topi/Sociology diunduh 17Januari 2010.

Luxemburg. Jan Van dkk. 1984. Pengantar Ilmu Sastra (terjemahan Dick Hartoko). Jakarta: PT. Gramedia.

Nyoman Kutha Ratna 2004. Teori, Metode, dan Teknik Penelitian Sastra. Yogyakarta: Pustaka Pelajar.

Nugraheni Eko Wardani.2009. Makna Totalitas dalam Karya sastra. Surakarta: LPP UNS dan UNS Press.

Nicoll,Laurence. Freedom and Contingency in Russian and Scottish Fiction. Journal of Scottish Literature. http:Ilwww.internationaljournal.com yang diunduh 16 Januari 2010.

Panuti, Sujiman. 1994. Memahami Cerita Rekan. Jakarta: Pustaka Jaya.

Purwanto. 2000. Kebudayaan Lingkungan dalam Perspektif Antropologi. Yogyakarta: Pustaka pelajar

Rachmat Djoko Pradopo.2002.Kritik Sastra Indonesia Modern. Yogjakarta: Gama Media.

Saptono. 2007. Sosiologi SMA Jilid 3. Jakarta: Phibeta Aneka Gama.

Silberman , Melvin L. Active Learning .101 Cara Belajar Siswa Aktif. Bandung: Nusa Media.

Soerjono S. 1990. Sosiologi Ruang Lingkup dan Aplikasinya. Bandung: Remaja Rosdakarya.

Stanton, Robert.1964.An Introduction To Fiction.Washington.

Sudarna. 2007. Kajian Novel Roro Mendut, Genduk Duku dan Lusi Lindri Karya Y.B. Mangunwijaya (Telaah Sastra dengan Pendekatan Intertekstualitas). Tesis, Surakarta: Program Pascasarjana Universitas Sebelas Maret Surakarta.

Suminto A. Sayuti.2000. Berkenalan dengan Prosa Fiksi. Yogjakarta: Gama Media.

Sutopo, H.B. 2006. Metodologi Penelitian Kualitatif: Dasar Teori dan Terapannya dalam Penelitian. Surakarta: University Sebelas Maret.

Shofy.2009.Ekonomi Mikro dan Makro. Phttp://one.indoskripsi.com/node/clikc. diunduh 27 Mei 2010

Soerjono Soekanto.2005. Sosilogi Suatu Pengantar. Jakarta: PT Raja Grafindo Persada

Teeuw, A. 1984. Sastra dan Ilmu Pengantar Teori Sastra. Jakarta: Pustaka Jaya.

Umar Yunus. 1986. Sosiologi Sastera Persoalan Teori dan Metode. Selanggor:

Dewan Bahasa dan Pustaka.

Wahyudi Siswanto. 2008.Pengantar Teori Sastra.Jakarta: PT Grasindo.

Wellek, Rene dan Austin Warren. 1962. Theory of Literature. New York: A Harvest Broks.

Zainuddin Fananie. 2000. Telaah Sastra. Surakarta: Muhamadiyah UniversityPress. 